Volume 5 Number 1 September 2021

\title{
The Effect of Blended Learning of Student Teams Achievement Division (STAD) and Jigsaw Towards Higher- Order Thinking Skills
}

Sandi Kurniawan

Pendidikan Kejuruan, Universitas Negeri Malang, Indonesia sandykurniawan4949@gmail.com

\begin{tabular}{ll}
\hline Article History & Received : June $7^{\text {th }} 2021$ \\
& Revision : July 19th 2021 \\
& Publication : Sept 30th 2021 \\
\hline
\end{tabular}

\begin{abstract}
Higher-order thinking skills is an ability that all vocational high school students should have because vocational high school graduates are required to have the good soft skill and hard skill. The reality was their HOTS ability was low, as stated by several explanations from researchers and strengthened by the observation in vocational high school. This research aimed to find the students' learning activity through blended learning of Student Teams Achievement Division (STAD) model and jigsaw model, and their influence on the HOTS. This research was quantitative research using the quasiexperiment method of nonequivalent control group design with research subjects of 50 students that were chosen using simple random sampling. The data was collected using test instruments in multiple choices and descriptions and non-test tool in the form of observation sheets. The data then were analyzed with t-test sample independent test. The results showed that the usage of STAD and jigsaw blended learning made students more active and energized in following the learning activities. The direct learning model made students inactive and not excited during learning activities. Also, the blended learning of STAD and jigsaw had significant influence compared to the direct learning model on higher-order thinking skills.
\end{abstract}

Keywords: blended learning, STAD, Jigsaw; Learning Activity; Higher-order Thinking Skills

\section{INTRODUCTION}

According to the Teaching Knowledge Test Cambridge English, Higher-order Thinking Skills (HOTS) is the student's thinking ability consists of the ability to remember, restate, and refer without analyzing, examine information critically, creatively, be creative and be able to solve problems (Saliba et al., 2013). HOTS is the thinking skill that all vocational high school students in Indonesia must have (Fazriani et al., 2019). Vocational high school graduates must have the good soft skill and hard 
skill so that they could fully work after graduating (Fazriani et al., 2019). HOTS is closely related to soft skills; they are communication skill, critical thinking skill, leadership and others. Hard skill is a specific skill that students must have following their major, for example, design ability, operating lathe machine, welding, and more(Dwi Riyanti et al., 2016).

Many factors influence vocational high school students' HOTS, one being the usage of the learning model and technology that could push the students to be more active in developing their abilities. Ningsih (2018), explained the factors that influence students' HOTS: (1) physical development, especially the brain, in facing the problem, (2) basic knowledge understanding, (3) students' direct experience with the physical environment, (4) external demand and assistance, and (5) self-motivation.

In reality, vocational high school students' HOTS were still low because they had yet been well-trained, according to (Pamuja, 2017). This condition causes the students' higher-order thinking skill, a requirement in education, was not going well. In general, Indonesian students have low: (1) understanding complex information, (2) theory, analysis, and problem-solving, (3) tools usage, procedure and solving a problem, and (4) conducting an investigation (Fanani, 2018;Adnannudin et al., 2020). The researcher also conducted direct observation to analyze, and researcher noted that most of the learning activities still used teacher-centred learning. When the researcher was conducting field practice study in vocational high school, the researcher taught CNC machine engineering with basic competency to evaluate the failure of CNC milling machine result in XII class using teacher-centred learning (conventional). During learning, students tended to be passive and ignored the teacher's explanation. After all, the material was presented, the evaluation was started in the form of descriptions that consists of C4, C5, and C6 from HOTS category. Most students received below Minimum Completeness Criteria with the highest value interval was between 35 - 50.

Based on the above explanation, most students' results were below the Minimum Completeness Criteria, and several factors that caused it were the unsuitable learning model and students were not used to doing questions in the HOTS category (Sudarman, 2014). Following the statement, it can be concluded that the conducted learning process did not entirely shape the students to have critical and analytical thinking and to give conclusion and problem solving (Sani, 2019). Based on these problems, the teacher should use the correct learning model to realize students with good higherorder thinking skills. A learning model that can be used is the blended learning model between Student Teams Achievement Division (STAD) and jigsaw. Several types of research also found that learning model dramatically influences the learning result. 
The research of Achmadi (2015) opened that blended learning application in the learning process improved the achievement of Year XI students from the Machining Engineering Program in VHS Muhammadiyah 3 Yogyakarta. The statement was proved by the difference in the pretest and posttest scores of the experimental class. The average pretest score was 52.5, while the average posttest score was 78.6. This research aligned with the study of Yaniawati (2013) that stated that students' higher-order thinking skills taught using blended learning were better than conventional education with the averaging results of 68.13 .

Blended learning model between Student Teams Achievement Division (STAD) and Jigsaw is a combination of two learning models and utilizes the information technology and communication through a gadget that is connected to the internet to support the learning activity. Blended learning between Student Teams Achievement Division (STAD) and Jigsaw enables students to improve their skill and potential positive and diminish the argument that students only listen during the learning process. This model also improves the interest and motivates the students during the learning process. Besides, students have the freedom to find and process the information correlated with the learning material. In other words, students are accustomed to critical and analytical thinking on the content.

This model uses a group learning system where students were grouped in 4-5 to discuss and study together on the content. This model makes students active in cooperation and collaboration to finish the problem in the group. This model also utilizes technology to overcome the limited learning resources. Each group is facilitated with a gadget to access information through the internet. By using technology, students get vast knowledge of the material. This research was performed in Public Vocational High School 6 Malang.

Based on the relevant theories and researches, this study aimed to find: (1) the effect of blended learning between Student Teams Achievement Division (STAD) and jigsaw towards higher-order thinking skills, (2) students' learning activity using blended learning of Student Teams Achievement Division (STAD) and jigsaw, and (3) students' learning activity using direct instruction model.

\section{METHOD}

This research is pseudo-experimental. The design used nonequivalent control group design with 50 students as the subject consisted of 25 Year XII TPM 1 students and 25 Year XII TPM 2 students. The classes were selected by random sampling technique. Year XII TPM 1 was chosen as the experimental class, while Year XII TPM 2 
was chosen as the control class. The instruments in this research were test and non-test in CNC Milling Machine subject.

Test instruments were ten multiple choices and five descriptions, while the nontest instrument was observation sheets and questionnaires. The instrument validation was divided into two stages: content validation and construct validation. Two experts validated the content, and the test could be used after revision. Construct validation was given to 10 students that have taken the material $(\mathrm{r}$ table $=0.632)$. The reliability of the test was adequate (Cronbach's alpha $=0.418$ ). Below are the instruments of the Higher-order Thinking Skills.

Table 1 Outline of Higher Level Thinking Ability Instruments

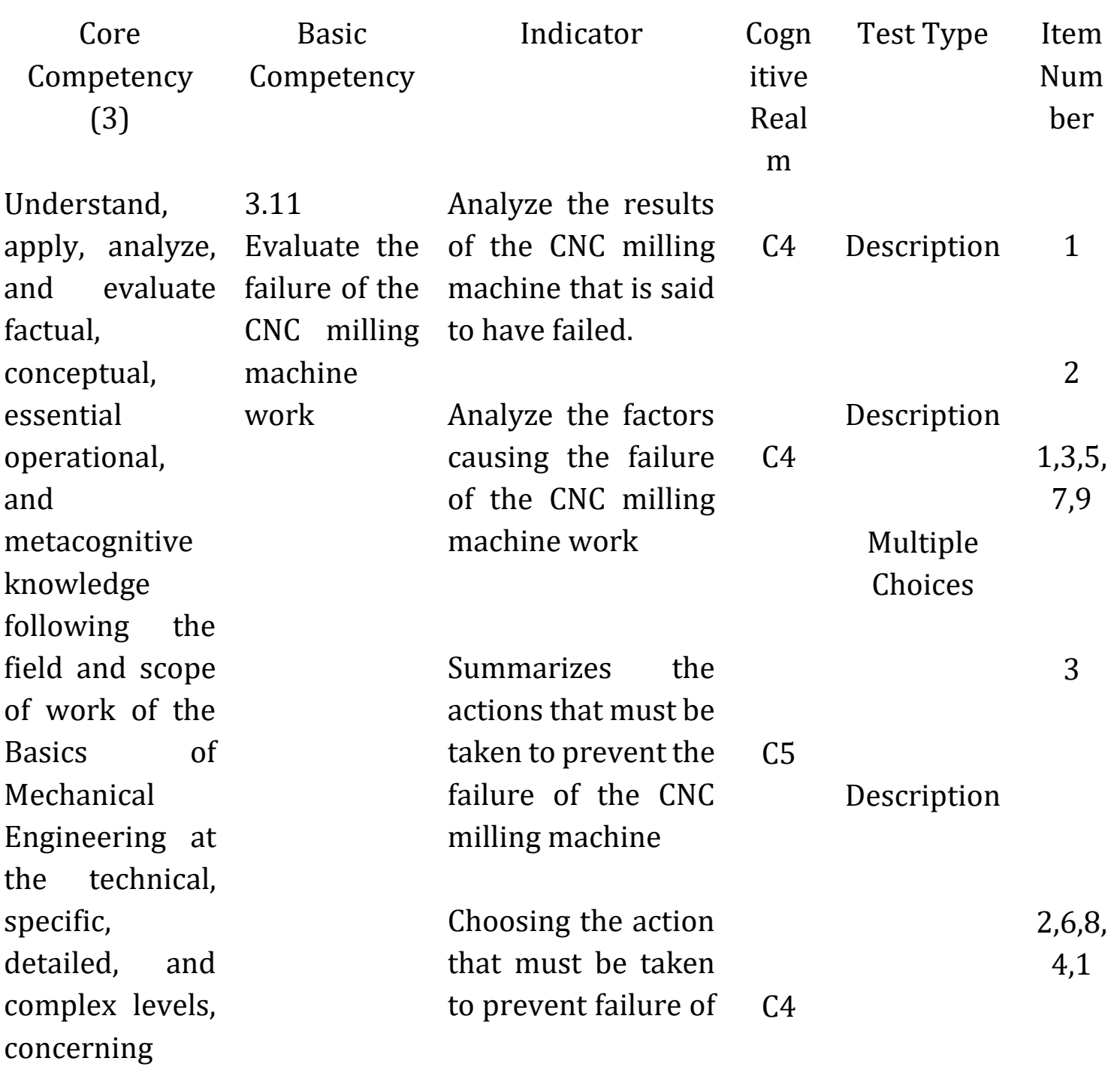




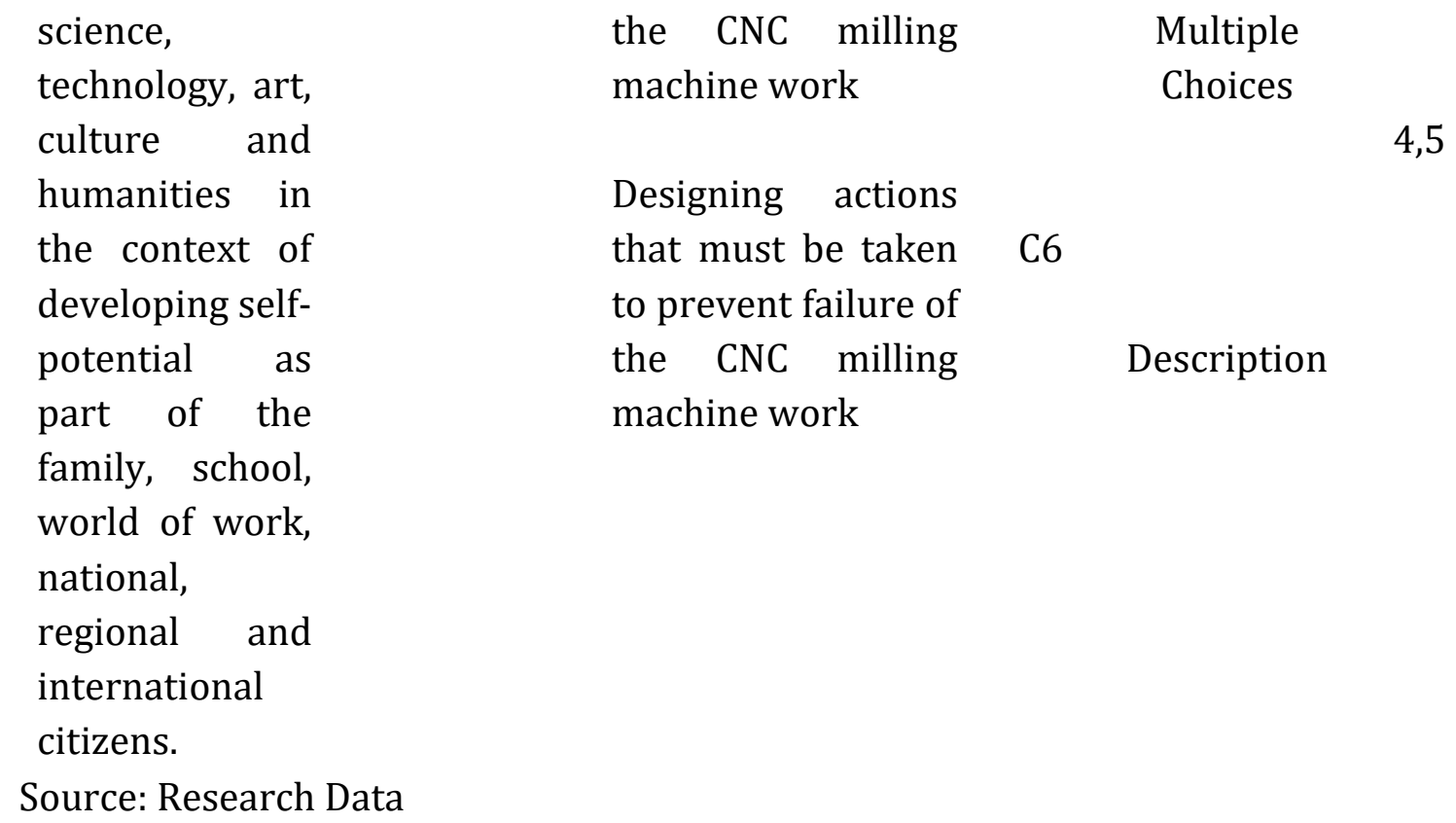

Source: Research Data

Designing actions

that must be taken $\mathrm{C} 6$

to prevent failure of

the CNC milling Description

machine work

Table 1 explains the outline of high-level thinking skills in which the Core Competencies and Basic Competencies are the competencies that must be conveyed to vocational high school students. The indicator is an aspect that students want to know through a test. Cognitive domain refers to students' high-level thinking abilities that are scored; the type of test is multiple choice and description. The item number is the numbering of questions according to the indicators seen.

The non-test instrument in this study was an observation sheet. The following is an outline table for student learning activities.

Table 2 Outline of Student Learning Activities Observation Sheet

Variable

Students

Learning

Activities
Indicator

Student activities during group discussions

Student activities to seek information and solve problems in group discussions

Student activities when expressing their ideas Student activities when organizing their friends' opinions $\begin{array}{cc}\text { Item } & \text { Total } \\ \text { Number } & \text { Items }\end{array}$

$1,2 \quad 2$

$3,4 \quad 2$

61


Volume 5 Number 1 September 2021

$\begin{array}{llr}\begin{array}{l}\text { Student activities in making presentations and } \\ \text { responding to the results of other group }\end{array} & 7,8 & 2 \\ \text { percentages } & & \\ \begin{array}{l}\text { Student activity while paying attention to the } \\ \text { teacher }\end{array} & 9 & 1 \\ \end{array}$

Source: Research Data

The data from this research: (1) students' pretest score in the experimental class before treatment, (2) pretest score from the control class, (3) posttest score from students' higher-order thinking skills in the experimental class using blended learning of STAD and jigsaw, (4) posttest from students' higher-order thinking skills in the control class using direct instruction model, (5) learning activity score of the experimental class, and (6) learning activity score of the control class.

This research analyzed the data using: (1) normality test with the Shapiro-Wilk method, (2) homogeneity test with the Lavene test method, and (3) hypothesis test using the Independent Sample T-test as a test of the difference between the experimental and control classes to determine the effect of STAD and jigsaw blended learning on HOTS.

\section{RESULTS AND DISCUSSION}

The normality test result showed that the pretest data in the experimental class had a significance of 0.069 , and the control class had a significance of 0.298 . The posttest data in the experimental class had a significance of 0.065 , and the control class had a significance of 0.155 . It is safe to conclude that the distributed data was homogenous. The learning activity analysis showed that the experimental class had a better score compared to the control class, averaging 70.56 . there were $28 \%$ of very active students, $28 \%$ of active students, and $44 \%$ of moderately active students during the learning process. Meanwhile, the analysis for the control class had an average value of 51.52 . there were $24 \%$ moderately active students, $36 \%$ less active students, and $40 \%$ passive students. The normality test can be seen in Table 3, whereas the homogeneity test results are in Table 4. 
Volume 5 Number 1 September 2021

Table 3 Normality Test Results

\begin{tabular}{lcccc}
\multicolumn{1}{c}{ Class } & Statistic & df & Sig. & \\
$\begin{array}{l}\text { Control class } \\
\text { pretest }\end{array}$ & 0,953 & 25 & 0,298 & \\
$\begin{array}{l}\text { Experimental class } \\
\text { pretest }\end{array}$ & 0,935 & 25 & 0,112 & \\
$\begin{array}{l}\text { Posttest control } \\
\text { class }\end{array}$ & 0,933 & 25 & 0,102 & \\
$\begin{array}{l}\text { Posttest Experiment } \\
\text { class }\end{array}$ & 0,946 & 25 & 0,200 & Source: \\
Processed & & & & Data
\end{tabular}

Table 4 Homogeneity Test Results

$\begin{array}{cccc}\text { Levene Statistic } & \text { df1 } & \text { df2 } & \text { Sig. } \\ 3,224 & 1 & 48 & 0,079\end{array}$

Source: Data Processed

The hypothesis was accepted ( $\operatorname{sig} p=0.000<\alpha=0.05$ ). There was a difference in students' higher-order thinking skills between using blended learning of STAD and jigsaw and direct instruction model. This result stated that blended learning between STAD and jigsaw influence students' higher-order thinking skills. Table 5 below presents the independent sample t-test results.

Table 5 Hypothesis Test Results of the Independent Sample T-test

$\begin{array}{cccc} & \text { Class } & \text { Sig. (2-tailed) } & \text { Mean } \\ \text { HOTS } & \text { Experiment } & 0,000 & 75 \\ & \text { Control } & 0,000 & 48\end{array}$

Source: Data Processed

\section{Discussion}

Students' learning activity using blended learning of STAD and jigsaw

The learning activity analysis results of students in the experimental class had an average score of 70.56. The score showed that students were in the active category. The blended learning of the Student Teams Achievement Division and jigsaw greatly 
influence students' learning activity, in line with the research of Khasanah (2018). This learning model enables the student to be active in seeking information, collaboration, and communicating within-group friends, following the research of (Berlyana \& Purwaningsih, 2019). Students' skills during in-class presentations also positively improved as the results of this learning model. Gadget usage also had an improvement in critical thinking and problem-solving.

The blended learning of STAD and jigsaw could be used as a reference during teaching because it has been proven based on empirical studies that the combination made students active during the learning process and influenced their higher-order thinking skills.

\section{Students' learning activity using direct instruction model}

Students' learning activity results in the control class had an average score of 51.52 . Students who were classified as quite active in the learning process are $24 \%$, less active students are $36 \%$, and students who were classified as passive are $40 \%$. The score showed that students were in the less active category. The direct instruction model in the control class was proven less effective in the learning process that enables students to be passive, in line with the research of Zahra, (Nuraini et al., 2018).

The direct instruction model did not always result in inactive students because there are many factors besides learning models that affect the learning activity, such as the teacher (Aliwanto, 2017). There are differences in the teachers' character, for example, the way new teacher and teacher who teaches for years in their approach to managing the class, how they explain the material, etc. These differences follow the research of Muttaqin et al (2018) that stated that direct instruction followed by discussion improved students' learning activity in chemical bounds material in Year X.1 Islamic High School 1 Surakarta School Academic Year of 2016/2017. The students' learning activity in Cycle I was 92.59\%.

A good learning activity resulted in positive students' results. Therefore, during teaching, the teacher should attend all components that influence learning activity so that students are interested in the process and indirectly affect the results.

\section{Blended learning of STAD and jigsaw towards higher-order thinking skills}

The posttest results of students' higher-order thinking skills using blended learning between STAD and jigsaw had an average of 75 . The score, categorized according to the criteria of Arikunto (2013), was in the adequate category. During posttest, the researcher observed how the students answered the multiple choices. Almost all students stated that the test was hard. The researcher also saw that students 
experienced difficulties in understanding the test's stimulus, and in return, affected the answer. From ten multiple choices, students could answer six questions correctly. Students who answered correctly the six tests only four out of 25 students. This occurrence proved that students had difficulty in answering higher-order thinking skills test, following the research's result of (Hasan, 2018). A factor that made students difficult in answering HOTS tests is students rarely solve difficulties with cognitive levels above C3. Thus, the teacher should apply the learning model and learning evaluation tool in higher-order thinking skills standard to accustomed to the students.

The blended learning model of Student Teams Achievement Division and jigsaw made students communicate and collaborate actively with their in-group friends to solve the problem from the teacher during the learning process (Garcia et al., 2017; Gambari \& Yusuf, 2017; Minarni et al., 2015). Based on the study of Pamuja, (2017), he found that achievement motivation greatly affected students' learning result. A similar matter also occurred in this research. This research found that achievement motivation during learning also affects students to focus on and follow the activity well. This objective supports the factor that forms the students' HOTS.

Blended learning of STAD and jigsaw greatly influence students' higher-order thinking skills because it consists of problem identification, analyzing causative factor, data collection, data interpretation, and conclusion development that require higherorder thinking skills. Applying this model gives students stimulation to optimize their higher-order thinking skills. The indicator of higher-order thinking skills is analysis, evaluation, and creation (Nugroho, 2018;Kristianingsih et al., 2016). These indicators are closely related to the syntax of blended learning between the Student Teams Achievement Division and jigsaw. Indirectly, the above syntax trains the students to have higher-order thinking skills.

Blended learning of STAD and jigsaw demand the students find the knowledge with the teacher's supervision (Sjukur, 2013). Blended learning of Student Teams Achievement Division and jigsaw improve their intellectual and skill in problemsolving. In other words, students have the freedom to solve their problems using any media. Thus, students obtain their in-depth knowledge and understanding and independently learn (Fazriani et al., 2019; Ma'ruf et al., 2019).

Knowledge obtained based on one's understanding will be more meaningful and impressive for students (Kristianingsih et al., 2016). This statement is proved by the average score of students that applied blended learning of the Student Teams Achievement Division and jigsaw because it was higher than the direct instruction model. This statement is also in line with the active learning principles that John Locke 
argued that knowledge based on experience would be more meaningful (Warsono \& Hariyanto, 2014).

The application of blended learning of the Student Teams Achievement Division and jigsaw in the first meeting in the experimental class analyzed the failure results of the CNC milling machine and evaluated the causative factors with the result. In the first step, the teacher organized the classroom according to the research design; then the teacher generally lectures the material. After, students were asked to discuss in the group about the task. Each group was given a gadget that was connected to the internet to support the learning process. During the students' discussion, the teacher only observed and instructed the students who did not understand the task. In the second stage, the teacher asked each group to present and other groups to respond to the presentation. The discussion results went well, and each group overall answered the task.

Although group discussion went well, there was a disadvantage and problem in the process. During the procedure, the researcher observed two students who less active and only followed the discussion. Besides, students also had difficulties in solving the problem with the cognitive level of $\mathrm{C} 4$ to $\mathrm{C} 6$, proved that students were not accustomed to answering the HOTS test. These obstacles became a challenge, particularly in VHS, to produce students with higher-order thinking skills by applying the correct system.

The second meeting in the experimental class discussed the conclusion to avoid the failure result in CNC milling machine and design treatment to prevent the failure. The system used a similar method to the first meeting, using blended learning of Student Teams Achievement Division and jigsaw. The gadget that was given greatly influenced the learning. Students were actively looking for materials by downloading and learning various failures with CNC milling machines through youtube, google, journals, etc. This event was in line with the purpose of $21^{\text {st }}$-century education that focuses on producing students with critical analytical thinking and able to conclude and problem-solving (Sani, 2019).

According to Vygotsky, higher-order thinking skills develop with the supervision of an expert colleague with higher expertise. That argument supports the blended learning of STAD and jigsaw to improve higher-order thinking skills. This type of education enables students to share their thinking with their in-group friends, communicating and collaborating on the problem given by the teacher, relevant to the statement (Hidayat et al., 2016). 
Volume 5 Number 1 September 2021

\section{CONCLUSION}

This study found that the learning activities of class XII students when using STAD and Jigsaw blended learning made students more active and enthusiastic in the learning process. In contrast, the learning activities of class XII students when using the direct learning model made students passive and did not want to develop higher-order thinking skills because they were too focused on paying attention to the teacher. Based on data analysis using independent sample t-test, the results of the analysis showed a significant number, so Ha was accepted and HO was rejected. Based on the results of this analysis, it can be concluded that there was a substantial effect of blended learning Student Teams-Achievement Division (STAD) and jigsaw on student HOTS.

High-level thinking skills were essential for students both in the school environment and in community life. Many factors influence high-level thinking skills due to the limitations of researchers. This study only focused on the learning model; it would be better if more in-depth research could be carried out on the high-level thinking skills of students in vocational high school.

\section{REFERENCES}

Achmadi, T. A. (2015). PENGARUH PENERAPAN BLENDED LEARNING TERHADAP PRESTASI BELAJAR SISWA KELAS XI TEKNIK PEMESINAN SMK MUHAMMADIYAH 3 YOGYAKARTA.

Adnannudin, A., Kusmana, S., \& Mascita, D. E. (2020). Pengembangan Penilaian Kognitif Berorientasi Hots Dan Pemanfaatannya Dalam Pembelajaran Bahasa Indonesia Di Smk. Jurnal Tuturan, 9(1), 1. https://doi.org/10.33603/jt.v9i1.3635

Aliwanto. (2017). Analisis Aktivitas Belajar. Jurnal Konseling GUSJIGANG, 3(1), 64-71. Arikunto, S. (2013). Prosedur Penelitian: Suatu Pendekatan Praktik. Rineka Cipta.

Berlyana, M. D. P., \& Purwaningsih, Y. (2019). Experimentation of STAD and Jigsaw Learning Models on Learning Achievements in terms of Learning Motivation. International Journal of Educational Research Review, 4(4), 517-524. https://doi.org/10.24331/ijere.628311

Dwi Riyanti, B. P., Sandroto, C. W., \& Warmiyati D.W, M. T. (2016). Soft Skill Competencies, Hard Skill Competencies, and Intention to Become Entrepreneur of Vocational Graduates. International Research Journal of Business Studies, 9(2), 119132. https://doi.org/10.21632/irjbs.9.2.119-132

Fanani, M. Z. (2018). Strategi Pengembangan Soal Hots Pada Kurikulum 2013. Edudeena, 2(1), 57-76. https://doi.org/10.30762/ed.v2i1.582

Fazriani, N., Supendi, D. A., \& Humaira, H. W. (2019). Pengaruh Pendekatan Higher Order Thinking Skill (HOTS) Terhadap Keterampilan Membaca Siswa Kelas X SMK 
Volume 5 Number 1 September 2021

Negeri 3 Kota Sukabumi. Stilistika: Jurnal Pendidikan Bahasa Dan Sastra, 12(2), 124-138. https://doi.org/10.30651/st.v12i2.2802

Gambari, A. I., \& Yusuf, M. O. (2017). Relative Effectiveness of Computer-Supported Jigsaw II , STAD and TAI Cooperative Learning Strategies on Performance, Attitude , and Retention of Secondary School Students in Physics Relative Effectiveness of Computer- Cooperative Learning Strategies on. Journal of Peer Learning, 10, 76-94. Garcia, B. A., Ed, D., Abrego, J., Ed, D., \& Robert, R. (2017). Using the Jigsaw Method for Meaningful Learning to Enhance Learning and Rentention in an Educational Leadership Graduate School Course. Global Journal of HUMAN-SOCIAL SCIENCE: G Linguistics \& Education, 17(5), 4-16.

Hasan, A. (2018). Higher Order Thinking Skill Siswa Sekolah Menengah Kejuruan Kompetensi Keahlian Teknik Pemesinan di Surakarta.

Hidayat, A., Wiharna, O., \& Sukrawan, Y. (2016). Implementasi model pembelajaran kooperatif tipe jigsaw untuk meningkatkan hasil belajar siswa pada kompetensi dasar perawatan kopling. Journal of Mechanical Engineering Education, 3(2), 145153.

Khasanah, U. (2018). Penerapan Model Pembelajaran Kooperatif Tipe Jigsaw Untuk Meningkatkan Aktivitas Belajar pada Mata Pelajaran Akuntansi Dasar Siswa Kelas X Akl 2 Smk Negeri 7 Yogyakarta Tahun Ajaran 2017/2018.

Kristianingsih, D. D., Wijayati, N., \& Sudarmin. (2016). Education Pengembangan LKS Fisika Bermuatan Generik Sains Untuk Meningkatkan Higher Order Thinking (HOTS) Siswa. Journal of Innovative Science, 5(1), 73-82.

Ma'ruf, A. H., Syafi'i, M., \& Kusuma, A. P. (2019). Pengaruh Model Pembelajaran Mind Mapping Berbasis HOTS terhadap Motivasi dan Hasil Belajar Siswa. Mosharafa: Jurnal Pendidikan Matematika, 8(3), 503-514.

Minarni, E., Ahman, E., \& Budiawati, N. (2015). The Effectiveness of Implementation of Cooperative Learning Model Using Student Teams Achievement Divisions (STAD) and Jigsaw to Students Analysis Capability. International Journal of Research and Review, 2(6), 343-347.

Muttaqin, N. H., Yamtinah, S., \& Utomo, S. B. (2018). Penerapan Model Pembelajaran Langsung (Direct Instruction) Disertai Diskusi dan Media Hyperchem untuk Meningkatkan Aktivitas dan Prestasi Belajar pada Materi Ikatan Kimia Kelas X 1 SMA Islam 1 Surakarta Tahun Pelajaran 2016/2017. Jurnal Pendidikan Kimia, 7(1), 62. https://doi.org/10.20961/jpkim.v7i1.24564

Ningsih, T. M. (2018). Pengaruh model pembelajaran kooperatif tipe think pair share dalam sistem pembelajaran blended terhadap kemampuan berpikir tingkat tinggi (higher order thinking skills). 
Nugroho, R. (2018). Higher Order Thinking Skills. PT Gramedia Widiasarana Indonesia. Nuraini, Fitriani, \& Fadhilah, R. (2018). HUBUNGAN ANTARA AKTIVITAS BELAJAR SISWA DAN HASIL BELAJAR PADA MATA PELAJARAN KIMIA KELAS X SMA NEGERI 5 PONTIANAK. Ar-Razi Jurnal Ilmiah, 6(1), 30-39.

Pamuja, I. (2017). Pengaruh Model Pembelajaran Inkuiri Terbimbing dan Motivasi Berprestasi terhadap Kemampuan Berfikir Tingkat Tinggi.

Saliba, G., Rankine, L., \& Cortez, H. (2013). The Fundamentals of Blended Learning. In University of Western Sydney. http://scholar.google.com/scholar?hl=en\&btnG=Search\&q=intitle:Fundamentals +of+Blended+Learning\#4

Sani, R. (2019). Pembelajaran Berbasis HOTS (Higher Order Thinking Skills). Tira Smart.

Sjukur, S. B. (2013). Pengaruh blended learning terhadap motivasi belajar dan hasil belajar siswa di tingkat SMK. Jurnal Pendidikan Vokasi, 2(3), 368-378. https://doi.org/10.21831/jpv.v2i3.1043

Sudarman, S. (2014). Pengaruh Strategi Pembelajaran Blended Learning Terhadap Perolehan Belajar Konsep Dan Prosedur Pada Mahasiswa Yang Memiliki SelfRegulated Learning Berbeda. Jurnal Pendidikan Dan Pembelajaran (JPP), 21(1), 107-117.

Warsono, \& Hariyanto. (2014). Pembelajaran Aktif: Teori dan Assesmen. Remaja Rosdakarya.

Yaniawati, R. P. (2013). E-Learning to Improve Higher Order Thinking Skills ( HOTS ) of Students. Journal of Education and Learning, 7, 109-120. 